\title{
臨床研修医への放射線教育から見えてきたもの 一放射線の理解とリスク認知度の解析一
}

\author{
松田尚樹*，三浦美和*，山内基弘*，奥野浩二** \\ *長崎大学先導生命科学研究支援センター \\ 852-8523 長崎県長崎市坂本 1-12-4 \\ **長崎大学病院 \\ 852-8501 長崎県長崎市坂本 1-7-1
}

\begin{abstract}
東京電力福島第一原子力発電所事故以来，医療スタッフに対する放射線教育の拡充が求められて いるが, その中心的存在となる医師の放射線に関する知識の程度は明らかではない。本研究では, 医師としてのスタートラインに立った臨床研修医のオリエンテーションにおける放射線研修時に確 認問題とアンケートを実施し, 放射線の理解とリスク認知の状況を調べた。その結果, 放射線の理 解度では放射線の健康影響, 次いで放射線の基礎と安全取扱いについて高く, 放射線関連の諸規則 や規制科学は全般に低かった。しかし，いずれの分野においても，よく質問されやすいようなごく 基本的な内容において, 理解度が低いものが見られた。放射線に関連したリスク認知度は, X 線検 查の受診と放射線診療の実施に対する認知は「リスクは気にしない」程度，その一方，原子力発電 と原発の近隣地域での居住については「リスクがあるのでなるべくなら避けたい」レベルで, いず れも福島原発事故後の時間経過にかかわらずほぼ一定を示した。以上の傾向は, 従来の他の職種や 学生によるリスク認知分布傾向と同様であった。研修医が今後, 専門性を獲得していくにともない 理解度とリスク認知度も多様化することが考えられるため, 継続的から反復的な基本的事項及び最 新トピックスの研修の必要性が示唆された。
\end{abstract}

Key Words : medical resident, radiation education, risk perception

\section{1. 緒 言}

「放射線と健康」にかかわる医師の役割は, おそらく医師が感じている以上に大きい。放射 線診療を受ける患者は, またその補助介助を行 う看護師らコメディカルスタッフは, 医師から の適切な指導と助言に基づき安心して受診し, あるいは職務を行う。そのため医学教育モデ ル・コア・カリキュラム (平成 22 年度改訂版) では，放射線は「B 医学一般-2 個体の反応-(3) 生体と放射線・電磁波・超音波」及び「F 診療 の基本 -2 基本的診療知識-(7)放射線等を用い る診断と治療」において取り上げられており, 放射線と健康にかかわる到達目標として, 放射 線と放射能の種類, 性質, 測定法と単位, 放射
線の人体（胎児を含む）への影響の特徵（急性 影響と晚発影響等), 種々の正常組織の放射線 感受性の違い, 放射線の遺伝子, 細胞への作用 と放射線による細胞死の機序, 局所的・全身的 障害, 放射線診断・治療による副作用と障害, 放射線防護と安全管理等が説明できることが到 達目標として挙げられている ${ }^{1)}$ 。東京電力福島 第一原子力発電所事故 (以下「福島第一原発事 故」という）後の健康被害に対する全国民的な 混乱の理由の一つとして「放射線教育」の不備 が挙げられているが, このようなカリキュラム に基づく医学教育における到達目標の達成度は 明らかではない。

2004 年より始まった新医師臨床研修制度に より, 医師国家試験に合格後の 2 年間の臨床研 
修が義務づけられ，この導入教育の際に院内で 必要とされる基礎知識やコンプライアンスにか かわる集中教育が可能となった。長崎大学病院 ではこの機会を利用して，電離放射線障害防止 法に基づく放射線教育を講義と実習を組み合わ せて行い，研修に必要な放射線診療従事者資格 の要件としている。ここでは法に定められた項 目とともに実践的な情報も提供し，またその理 解度を放射線の基礎，放射線による健康影響， 放射線に関する法規則の 3 点についての確認問 題から判定してきた。さらに，放射線のコミュ ニケーションを左右する放射線リスク認知度と 不安度についても調查を行ってきた。本研究で は，福島第一原発事故後の 2011 年 4 月以降の 研修医放射線教育に対するこれらの確認問題と 調査の結果に基づき，スタートラインに立つ医 師による放射線の理解とリスク認知の状況を解 析し，医師の卒前，卒後教育に求められる実践 的な放射線に関する知識について考察する。

\section{2. 方 法}

\section{$2 \cdot 1$ 確認問題}

本研究では, 福島第一原発事故直後の 2011 年 4 月から 2014 年 4 月まで，計 4 回実施され た研修医オリエンテーション（長崎大学病院医 療教育開発センター主催）の受講者を解析対象 とした。各年度の臨床研修医数は, 順に $36 ， 35 ， 55 ， 37$ 名で，合計 163 名であった。 4 月 1 日より約 1 週間行われる研修医オリエンテ ーションの 3 日あるいは 4 日目に放射線研修が 組まれ，午前中には「放射線の基礎と安全取扱 い，「放射線の健康影響」，「放射線関連法令及 び諸規則」についての講義, 午後に ${ }^{226} \mathrm{Ra}$ チェ ッキングソースを用いた放射線測定実習を行っ た。講義は先導生命科学研究支援センター及び 医療技術部, 実習は先導生命科学研究支援セン ターに所属する教員及び技術職員が担当した。 確認問題は講義と実習の間に出題し，実習後に 回収した。内容は放射線の基礎，放射線による 健康影響，放射線に関する法規則を大分類とし，
正誤問題を各 10 題ずつ出題した（Table 1)。 採点後の答案は正答及び解説とともに各研修生 に返却した。

\section{$2 \cdot 2$ リスク認知}

Table 2 に示す 10 の活動のリスクを，5段階 尺度法（1：リスクはほとんどないと思う，2： リスクはあるのかもしれないが気にしない, 3 ： リスクがあることは知っているが，それでも行 う，4：リスクがあるのでなるべくなら避けた い，5：リスク大きいので絶対避けたい）で定 量化した。また，(1）X 線検査を受けるときの 不安の有無，（2）放射線診療業務を行うときの 不安の有無，（3）X 線検查を受ける患者に放射 線についてうまく説明する自信，（4）看護師に 対して放射線についてうまく説明する自信，に ついての質問も行った。これらの調査のための 回答用紙も確認問題と同時に配布し，実習終了 後に回収した。

\section{3. 結 果}

\section{$3 \cdot 1$ 放射線の理解}

4 回実施した研修の各回における確認問題正 答率（正解者数/受講者数）の平均を Fig. 1 に 示す。10 問ずつの大分類ごとの正答率は, 放 射線の基礎と安全取扱い $66.5 \%$ 放射線の健 康影響 $85.8 \%$ ，放射線関連法令及び諸規則 $54.9 \%$ であった。放射線の基礎と安全取扱い では，医療に用いられる放射線の種類について は 70\% 以上の正答率が得られたが，ポジトロ ンとプロトンの混同（問 $6,27.4 \%$ )，X 線検 查後に放射線が残存するという誤解（問 7 , $58.6 \%)$, 及び $125 \mathrm{I}$ シード治療病室内の空気中放 射能濃度の変化の有無（問 8，43.7\%）につ いての正答率が特に低かった。この 3 問の正答 率の年次変化を Fig. 2A に示す。正答率 $20 \%$ 程度の振れ幅が年次間で見られているが，ポジ トロンの理解は一定に低く，2014 年はX 線撮 影室とシード治療がポジトロン程度にまで低下 し，いずれも正答率 $50 \%$ を下回った。健康影 


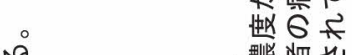

ह

중

12

开了단

"尺

略冚卧

比些

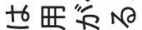

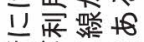

歯”闪

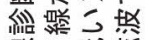

略的出楚

蓝

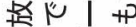

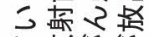

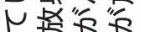

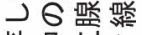

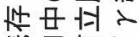

憋区盗

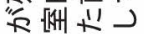

眹, $\pm-U$

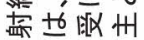

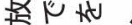

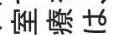

噮紫得行 $N G 6$

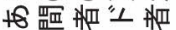

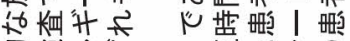

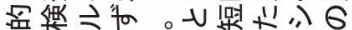
覴洲和

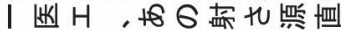

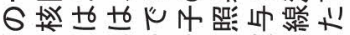

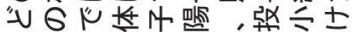

和"

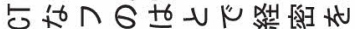

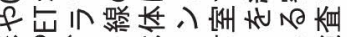

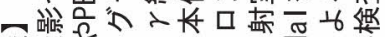

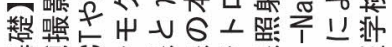

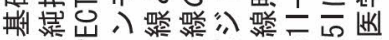
6 泪的的的兴 疁

监

id

-

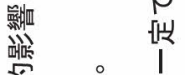

爵 =

in is

到

保。崩

यू

iI $18+4$

崰

比

i) IJ to

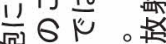

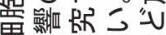

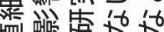

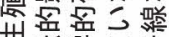

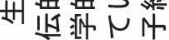

مอำ

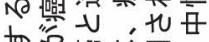

$\mathrm{No}$

iN

篮

Not

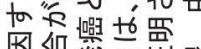

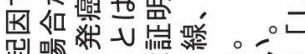

型等 $N$ IJ th

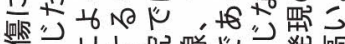

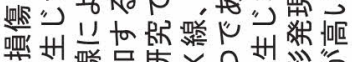

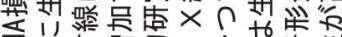

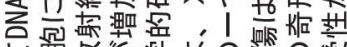

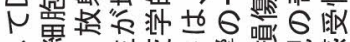

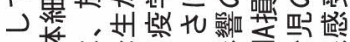

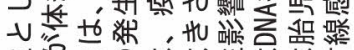

H合 6 世

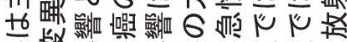

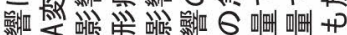

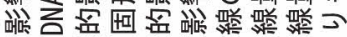

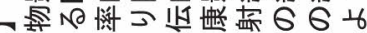

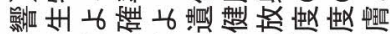

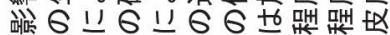

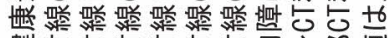

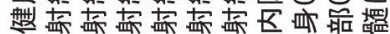

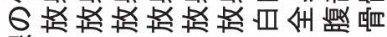

监
No

$+8$

啋

战

正

1)

保姲

哭落

No 梌

- to 迎

正 +P

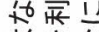

+6 姑保

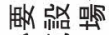

。畓

Non正落

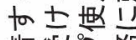

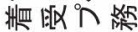
赤就 牒

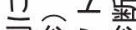

爵留入犁

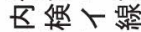

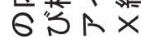

I $166 \mathrm{~V}$

的波"

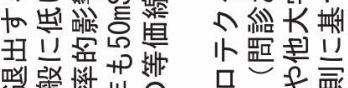

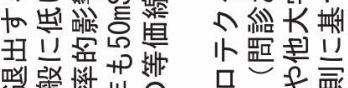

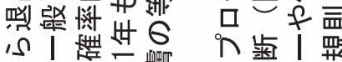

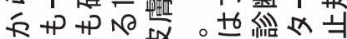

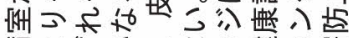

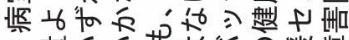

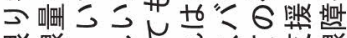

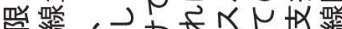

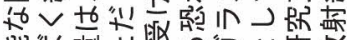

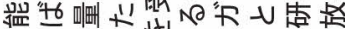

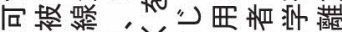

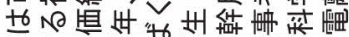

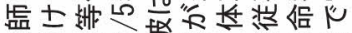

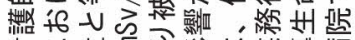

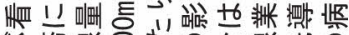

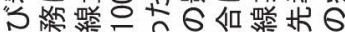

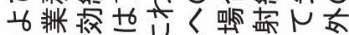

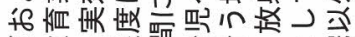

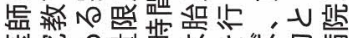

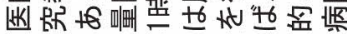

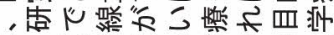

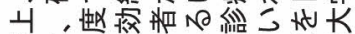

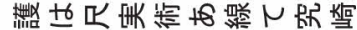

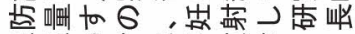

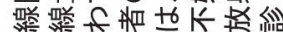

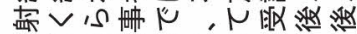

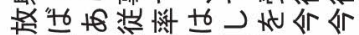

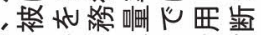
t6́

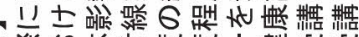

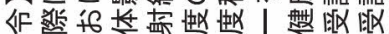

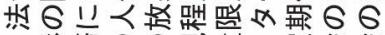

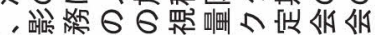

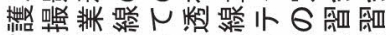

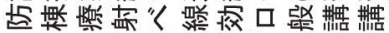

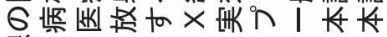
器

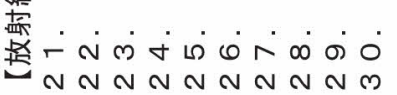


Table 2 Ten potential hazards presented in a questionnaire
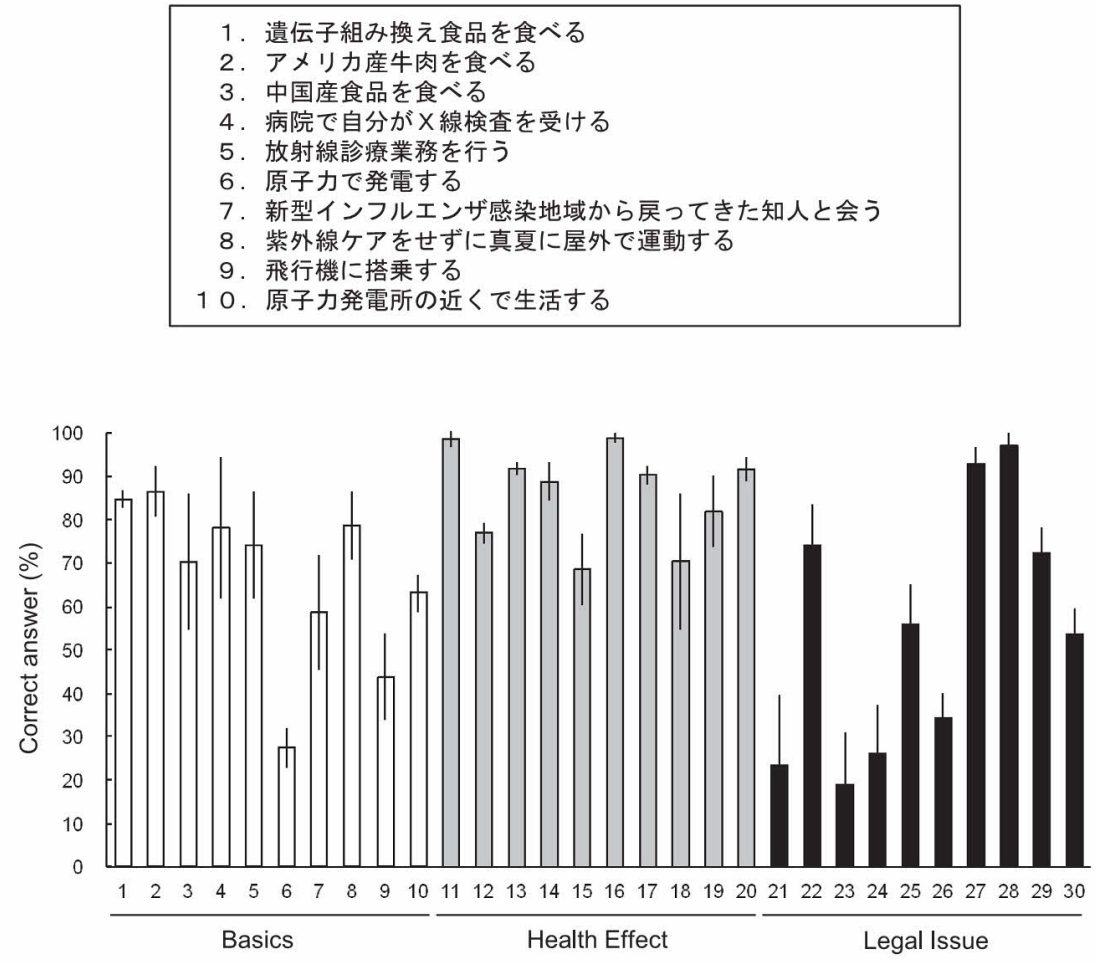

Fig. 1 Results of review exercises in basics, health effect, and legal issue of radiation. Each column and bar represents the mean percent of correct answer from annual four classes for thirty independent questions and the standard deviation of the mean, respectively.

響については全体として高い正答率が得られ (Fig. 1), 突然変異とがん, 遺伝的影響の関係 (問 12), 放射線の遺伝的影響に疫学的証拠が あるとする誤解 (問 15)，全身 CTによる DNA 損傷生成（問 18），についての正答率が比較的 低かったものの，いずれも約 70\% は超えた。 年次別トレンドもほぼ一定あるいはわずかに上 昇傾向を示し，2014 年には 80\%の正答率が得 られた (Fig. 2B)。それに対して，放射線関連 法令及び諸規則のうち，病棟撮影の際に確保す べき線源との距離（問 $21,23.5 \%$ ), 実効線量 と等価線量で表される放射線影響の指標（問 $23 ， 18.9 \%$ ), 実効線量限度（問 24，26.1\%), 実効線量限度での不妊あるいは胎児への影響 （問 26，34.3\%）はいずれも正答者が約 $1 / 3$ に
満たず，全体の中でも特に低い正答率であった (Fig. 1)。しかし年次別にはわずかに正答率が 改善している傾向も見られた（Fig. 2C）。

\section{$3 \cdot 2$ リスク認知}

各活動に対する全研修医による平均リスク認 知を Fig. 3 に示す。全ての活動に対するリス ク認知度平均は 2.83 で, 年次別には 2011 年 $2.87,2012$ 年 $2.97,2013$ 年 $2.67,2014$ 年 2.90 と年ごとにわずかに変化したが, 全体として「リ スクがあることは知っているが，それでも行 う」を少し下回る程度のリスク認知であった。 放射線に関するリスク認知のうち，X 線検查の 受診と放射線診療の実施に対するリスク認知は 平均認知度よりも低く，その一方，原子力発電 


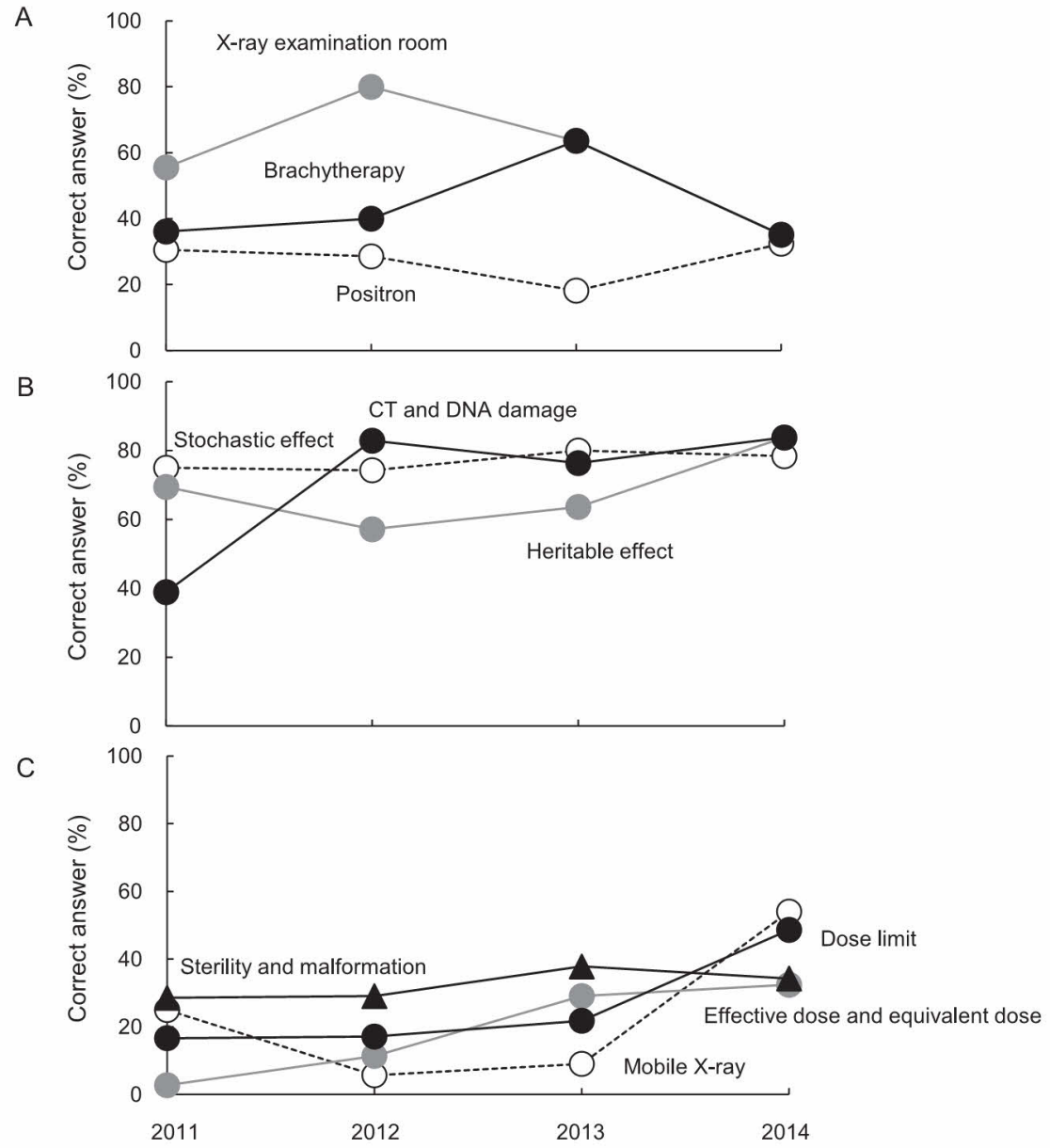

Fig. 2 Annual trend of the results of review exercises. Three questions with the poor results are shown in basics (A), health effect(B), and legal issue (C) of radiation.

と原発の近隣地域での居住については平均認知 度を超え，特に後者は「リスクがあるのでなる ベくなら避けたい」レベルに達した。全体の中 では，この原発の近隣地域での居住のリスク認 知が最大となり，次いで新型インフルエンザ感 染地域から帰還した友人からの感染リスク, 中 国産食品の順となった。放射線診療の実施と遺 伝子組換え食品とアメリカ産牛肉, 及びX 線 検查受診と飛行機搭乗が, それぞれほぼ同程度 のリスク認知度であった。これらの放射線関連 リスクの認知は, 福島第一原発事故後の時間経 過にかかわらずほほ一定であった（Fig.4）。

Figure 5 には業務への不安や自信について
の，各年別の結果を示す。10～20\%の研修医 は放射線の受診が不安であると答え，放射線業 務に不安があるとする回答は $30 \%$ 前後で，い ずれも増加傾向が見られた。その一方で，患者 への説明，及び看護師への説明に自信があると 答えた研修医も増加傾向にあり, 最新の研修で は約 $20 \%$ の研修医が自信ありと回答した。

\section{4. 考 察}

確認問題は講義後に出題しているため，回答 者にとって手がかりは全て与えられているが, 短時間の講義の中で全てを吸収することは難し い。したがって，講義の理解度に加えて，講義 


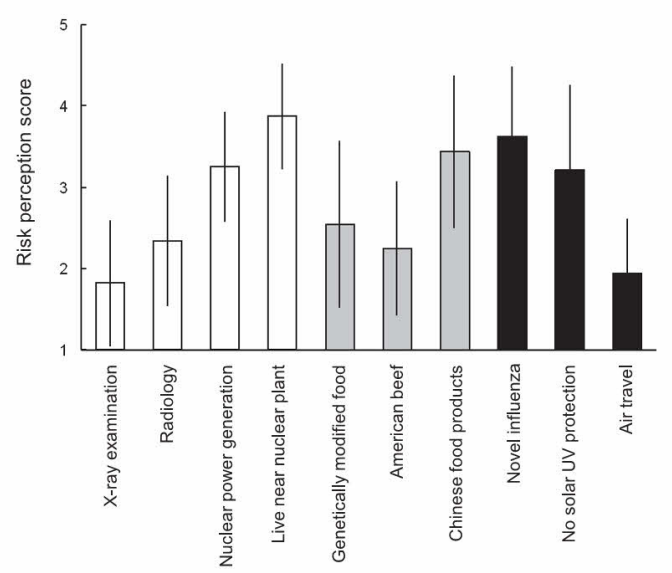

Fig. 3 The average risk perception scores by medical residents. Each column and bar represents the mean and standard deviation of the mean from 163 residents, respectively.

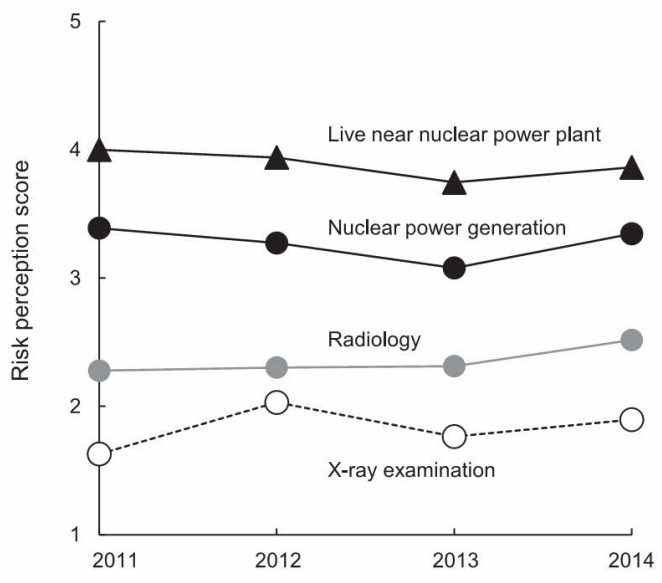

Fig. 4 Annual trend of risk perception scores for radiation-related activities.

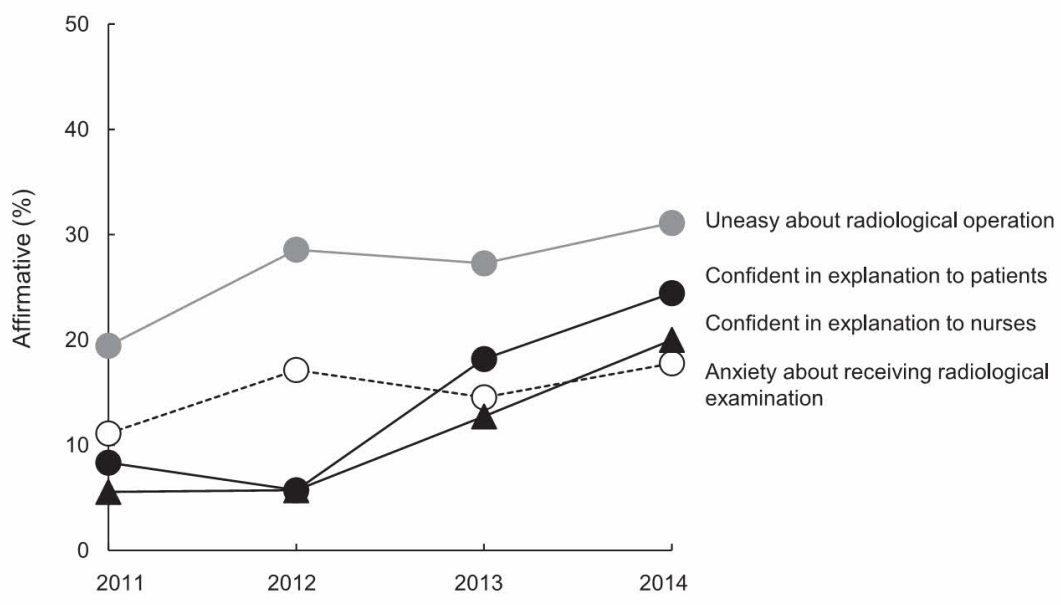

Fig. 5 Annual changes of the mental state of medical residents. The percent of residents who answered affirmative to four questions are shown.

前の知識レベルもまた回答率に反映しているも のと思われる。基礎知識のうち，医療放射線の 種類に関しては概ね良好な回答率であったが, その中でポジトロンをプロトンと誤解する例は 極めて多かった。PET 検査の増加に伴い医師 から患者への説明機会も増える可能性はあるが, 陽電子の英訳は基本的に書面説明で済ませるこ とのできる内容であり，医療説明上大きな問題
にはならないであろう。また，密封小線源であ る ${ }^{125} \mathrm{I}$ シード治療病室と非密封 ${ }^{131} \mathrm{I}$ カプセル製剤 による内照射病室の放射線環境についても混乱 が見られたが，これも，今後実際に治療にかか わる前の周知を徹底することで身に付くものと 思われる。それに対して，X 線撮影後に撮影室 には放射線が残存していないという点は基本的 事項であり，から診断機会も最も多いにもかか 
わらず，約半数が誤解していた。この点は医学 部 3 年生の講義でも再三ふれているが，定着し ていない。また，筆者らが別に実施している看 護職員への放射線教育においても同様の回答が 極めて多い。卒後においても, 再教育用の機会 を捉えた反復したリマインド教育が必須である。 全般として良好であった健康影響に関する出 題の中では，放射線の遺伝的影響について， $30 \%$ を超える研修医が疫学的証拠ありと答え ていた。長崎では被爆者関連のニュースが連日 報道され，放射線による健康被害体験を目や耳 にする機会も多い。筆者らが大学外で行う課外 授業での印象では, 小中学校の生徒のみならず 教諭であっても, ほとんどが放射線の遺伝的影 響ありと信じているようである。そのような地 域性も寄与している可能性もあるが，将来はと もかく現時点で放射線の遺伝的影響はヒトでは 認められておらず),3)，場合によっては，医師 はそれを伝える役目にあることを考えると，こ の正答率はあまりにも低い。

法規則に関しては，おそらく初めて受講する 内容であり, 実効線量限度など規制科学的に導 かれた数值の記憶が低いのはやむを得ないであ ろう。実効線量限度を細かく記憶するよりも， むしろ実効線量限度の概念を理解する方が重要 であるが，その意味で，実効線量限度において 健康影響が生じるという誤解は解くべきであり， これも反復的な情報提供が必要である。出張撮 影については, 正しくは撮影に必要な医療従事 者以外は $2 \mathrm{~m}$ 以上離れれば良いことと示され ており4)，これを適用すれば，病棟撮影時にも 室外にまで退出しなければならない状況はさほ ど多くないと考えられる。研修医がこのような 放射線防護上の正しい理解を身につけることは， 患者家族や看護スタッフに対しても安心を与え ることになろう。

年次トレンドとして，これらの正答率の低か った項目の理解度はわずかながら上昇している 程度であった。確認問題全ての平均正答率も 2011 年から順に $68.1 \%, 69.2 \%, 65.3 \%, 73.5 \%$
で，2014 年は特に高值を示したものの，安定 した上昇ではない。したがって本研究の対象と した限られた集団で見る限り, 原発事故後, 医 学部の卒前教育において放射線の理解度が高ま っている確実な証拠は見られない。その一方で, 研修医の放射線に対する不安と，放射線を説明 する自信が両面的に増加している，すなわち不 安層と自信層が両方とも増えていることを示唆 する結果が得られたことは興味深い。少なくと も放射線に対する関心は高まっている可能性が あり，原発事故及びそれ以降の社会状況が，そ の要因の一つなのかもしれない。

種々の活動に対する研修医のリスク認知度は, 筆者らがこれまでに調査してきた学生, 看護師 の女性の認知度よりも低い傾向にあり ${ }^{5)}$ ，これ はルーマニア6)及びカザフスタンフにおけるリ スク認知調查の結果と一致する。しかし，リス ク対象間の相対的な分布は, 学生, 看護師とほ ほ同様の結果を示した。すなわち原子力関連り スクは高く，医療放射線関連リスクは低く，い ずれも大きな年次変化は見られない( ${ }^{6)}$ 。今後の 専門化と経験の積み重ねにより研修医の認知度 も変化していくことも考えられるが，専門性が 増すことによってむしろバラッキが増える可能 性もある。たとえ放射線の専門家であっても， 専門性，性別，リスクを受ける対象によって放 射線リスク認知には多様性がある ${ }^{8)}$ 。また，人 を対象にする医師は，実験と理論に依存する科 学者よりも高い放射線リスク認知度を示すこと も報告されている7)。したがって，キャリアと ともに画一的にリスク認知度が下がるとは考え られない。

放射線に関する卒前教育の拡充には一定の効 果があるかもしれないが，実際的には時間的に も量的にも限度がある ${ }^{9)}$ 。放射線業務従事者教 育等の院内研修, 産業医制度指定研修会（作業 環境管理，有害業務管理）等，また e-learning による生涯教育 ${ }^{10)}$ を通じて，今回，基本的事項 であるにもかかわらず特に理解度の低かった項 目や, 社会的要請度の高いものについての卒後 
の継続反復教育が，医師本人のみならず患者や スタッフへの影響力も含めて極めて重要である。

\section{文献}

1）文部科学省高等教育局医学教育課, 医学教育モ デル・コア・カリキュラム（平成 22 年度改訂 版) 歯学教育モデル・コア・カリキュラム（平 成 22 年度改訂版）の公表について，2011年 3 月 31 日 (2011)

http ://www.mext.go.jp/b_menu/shingi/chousa /koutou/033-1/toushin/1304433.htm

2) Izumi, S., Koyama, K., Soda, M. and Suyama, A., Cancer incidence in children and young adults did not increase relative to parental exposure to atomic bombs, Br.J. Cancer, 89, 1709-1713(2003)

3）被爆二世健康影響調查科学 - 倫理合同委員会, 被爆二世健康影響調査報告, 平成 19 年 3 月 (2007)

http : //www.rerf.or.jp/radefx/genetics/FOCS reportJ.pdf

4）厚生省医薬安全局安全対策課長通知，在宅医療 におけるエックス線撮影装置の安全な使用につ いて, 平成 10 年 6 月 30 日医薬安発第 69 号 (1998)

http : //www.japal.org/contents/19989639_69. pdf

5) Miura, M., Yoshida, M., Takao, H. and Matsuda, N., Perception of risks from radiation by faculty and students in Nagasaki University, Radiat. Safety Manag., 7, 1-5 (2008)

6) Mihai, L. T., Milu, C., Voicu, B. and Enachescu, D., Ionizing radiation - Understanding and acceptance, Health Phys., 89, 375-382 (2002)

7) Purvis-Roberts, L. K., Werner, C. A. and Frank, I., Perceived risks from radiation and nuclear testing near Semipalatinsk, Kazakhstan : A comparison between physicians, scientists, and the public, Risk Analysis, 27, 291-302 (2007)

8）三浦美和，林田りか，高尾秀明，小野孝二，松 田尚樹，放射線専門家による放射線リスクの認 知一東京電力福島第一原子力発電所の事故直前 の状況，日本放射線安全管理学会誌，12，46-53 (2013)

9）遠藤啓吾，放射線教育について〜反省を糧に, さらなる拡充へ〜，平成 25 年 8 月 7 日，首相官
邸原子力災害専門グループからのコメント第 46 回 (2013)

http : //www.kantei.go.jp/saigai/senmonka_g 46.html

10）放射線医学総合研究所, 診療に役立つ放射線の 基礎知識，被ばく医療に関する e-learning，2013 年 3 月 (2013)

http : //www.nirs.go.jp/publication/rs-sci/e learning/index.html

\section{Abstract}

Radiation Education to Medical Residents-Their Understanding and Risk Perception of Radiation-

Naoki MatsudA*, Miwa MiURA*, Motohiro YAMAUChI* and Koji OKunO** :*Nagasaki University Center for Frontier Life Sciences, 1-12-4 Sakamoto, Nagasaki-shi, Nagasaki Pref. 852-8523, Japan, **Nagasaki University Hospital, 1-7-1 Sakamoto, Nagasaki-shi, Nagasaki Pref. 852-8501, Japan

The improvement of radiation education to medical staffs is required in particular after the nuclear accident at the TEPCO Fukushima Daiichi nuclear power station; however, the comprehension level of radiation by medical doctors has not been elucidated. Here we analyzed the understanding and risk perception of radiation by the medical residents by the results of the review examination and the questionnaire in the radiation education course for them from 2011 to 2014. Although the health effect of radiation was relatively well understood compared to the basics, safe handling, and legal issues, some primary and simple questions in all areas resulted in exceptionally low scores. The risk perception of radiation was high in the nuclear power generation and low in the medical radiation, which appeared stable in every year and similar to the radiation risk perception by other respondents. These findings suggest that the repeated education course for medical staffs is absolutely necessary to make them better understand radiation and updated continuously. 